\title{
INTEGRATED MANAGEMENT SYSTEMS
}

Over the past few years an increasing number of companies certified according to the requirements of ISO 9001:2008 for Quality Management System (QMS) but also according to the requirements of other standards, for example environmental management system according to ISO 14001:2004 (EMS) and / or a management system for Occupational Health \& Safety Management System, according to OHSAS 18001:2007, or other standards (ISO 22000, ISO 27000, etc.) can be seen in industrial sector and in services as well. Integration of management systems has become a key aspect of more sustainable management of a company. The aim of paper is to (1) better explain role of management systems implementation in enterprises, (2) point out necessity of their integration, (3) analyze common items of particular management systems, which is inevitable to their further integration, (4) point out some benefits and obstacles linked with integration.

Key words: Integration, management system, ISO standard, organization.

\section{Introduction}

In the past, a clear trend of our organizations was the quality management system certification in accordance with the requirements of ISO 9001 and 9002:1994 and according to the requirements of ISO 9001/2000 [5]. Today, we are meeting the increasingly frequent cases of entry of foreign capital in the Slovak market or development of partnership relations within the EU as well as the U.S., Britain, Canada, and their requirements (e.g. automotive industry) establishment and implementation of management system of environmental management according to ISO 14001 and management system of occupational safety and health at work in terms of specification OHSAS 18001 or system HACCP for food safety management, or requirements for information safety etc. [8]

Many larger and smaller organizations with foreign capital, or with the business primarily in foreign markets have now implemented the Integrated Management System (IMS) in line with international requirements, which assist for managing their dominant market position at home and abroad and in the immediate extent manage their losses from the poor quality of products, from negative impacts on the environment, or threat of safety and health at work [3]. At present it is assumed that the company operating on the market can not produce high-quality, if it is not managing its losses and doesn't consider environmental protection and safety of its employees beyond the legislative requirements of our country [2].

Ensuring the success of the organization implementing the various management systems in today's difficult economic situation becomes more and more obvious. Among the best known and most frequently applied internationally recognized standards can be included:

- Quality Management System (QMS),
- Environmental Management System (EMS / EMAS),

- Occupational Health \& Safety Management System (OHSAS) [4].

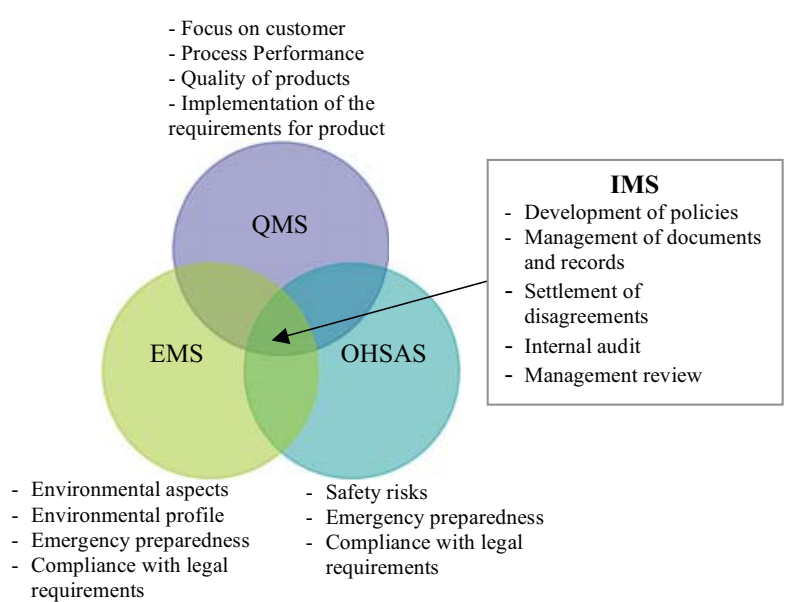

Fig. 1 Integration of management systems

\section{Characteristic of the most Commonly used Management Systems}

\section{Quality Management System}

Quality of products and production affects the welfare, efficiency and competitiveness of the business entity. The aim of the implementing quality management system in company is to create a good relation of employees to quality as a fundamental category of the market economy and make them produce this quality. Quality management system determines the prior characteristics

\footnotetext{
* Jana Chovancova ${ }^{1}$, Milan Majerník ${ }^{2}$, Jana Jurikova ${ }^{2}$

${ }^{1}$ University of Presov in Presov, Faculty of Management, Presov, Slovakia, E-mail: jchovancova@unipo.sk

${ }^{2}$ Technical University of Kosice, Faculty of Mechanical Engineering, Kosice, Slovakia, E-mail: milan.majernik@tuke.sk
} 
of the product, through which the company meets the identified needs of the market [2]. Setting the correct relationship between enterprise and market environment, is realized by using a quality management system.

Quality management system represents the organizational structure of enterprise, application of methods, tools and processes used for the implementation, maintenance and improvement of activities and their outcomes.

The current standard ISO 9001 monitors the company's processes and management system concerning customer requirements, product requirements and management of the risks related to quality of products and processes. Certification is a mark of maturity and credibility of a certain company and becomes a significant competitive advantage.

\section{Environmental Management System}

Environmental Management System according to standard ISO 14001 is a part of a complex management system that includes structure, planning activities, responsibilities, practices, procedures, processes and resources for the preparation, implementation, review and maintenance of environmental policy [4]. EMS is a part of the company's management system oriented to implementation of activities aiming to environmental protection. This means implementation (integration) of elements of environmental protection in decision-making processes and management of a company.

EMS is a management system related to environmental protection and is based on a series of ISO standards 14000. It is also the application of sustainable development specified in the 16 principles of Business charter adopted by the International Chamber of Commerce (ICC) for sustainable business development in 1991 and expanded on the principle of corporate social responsibility, which was adopted in 1997.

ISO 14000 series of standards represents a system of normative documents aimed mainly at:

- Environmental management systems with guide for documentation development.

- Audits as a form of verification of the status of environmental protection,

- Environmental performance evaluation of a company,

- Environmental labeling,

- Life-cycle assessment.

Though EMS implementation is not mandatory, concerning ever increasing legislative requirements it becomes inevitable especially for large enterprises.

\section{Health and Safety Management System}

Requirements of quality management system mostly in the area of working environment influence not only company's employees, but also public in close neighborhood. Therefore emphasis is put on meeting requirements of safety and health protection of employees regarding to new legislative requirements related to industrial accidents and protecting citizens living in the risk area [10].
The structure of OHSAS Standard is compatible with the essential elements of the legislation of most European countries and above mentioned standards ISO 14001 and ISO 9001 [11].

Similarly to the EMS the basis of the system is searching for threats and evaluation of resulting risks to employees, then underpin all possible risks and minimize their impact [8]. Today, regarding to our alignment with EU law, this principle is anchored in SR legislation.

Control system of work security is a vast system of organizational structures, procedures, processes and resources, which includes compliance with all legislation requirements [9]. Management of safe operations is part of top management of the company, and incorporates the implementation of these actions:

- Assign the same priority to the safety and health and environmental protection as economic aspects;

- Managing business the way which will increase the level of health protection of workers and environmental protection;

- Increasing awareness and responsibility of employees regarding to self health protection, with aim to motivate their cooperation in the field of work security.

- Integration of OHSAS requirements, as well as environmental protection to the designing and construction of all technological entities;

- Providing information to employees on safely managing activities within the system "man - machine - environment";

- Cooperation with national organizations, as well as with local authorities in preventing the occurrence of major accidents and to create conditions for health protection at work

\section{Approaches to the Integration of Management Systems}

Comparison and analysis of models and standards of management systems in terms of integration can be divided into three logical levels:

- Comparison or identifying common elements in all systems and their standards.

- Comparison or determine the common elements on the level of only two standards at the time.

- Comparison on the level of incompatibilities or specific elements of all standards.

Comparison or identifying common elements in all systems and their standards

It regards the determination of intersections of all three systems: quality $\cap$ environment $\cap$ safety.

About $80 \%$ of the elements of standards is common to all three aspects - quality, environment and security (see table 1).

ISO Guide 72:2001 Guidelines for the justification and development of management systems and standards arranges these common elements under the following main subjects:

- Policy,

- Planning, 
Comparing the elements of safety, environment and quality in particular standards

\begin{tabular}{|c|c|c|}
\hline OHSAS 18001 & ISO 14001 & ISO 9001:2000 \\
\hline Health and Safety Management System & Environmental Management System & Quality Management System \\
\hline 4.1 General requirements & 4.1 General requirements & 4.1 General requirements \\
\hline 4.2 OHSAS policy & 4.2 Environmental policy & 5.3 Policy of quality \\
\hline 4.3 Planning & 4.3 Planning & 5.4 Planning \\
\hline $\begin{array}{l}\text { 4.3.1 Planning of identification of danger, risk } \\
\text { assessment and risk management }\end{array}$ & 4.3.1 Environmental aspects & 5.2 Focus on customer \\
\hline 4.3.2 Legal and other requirements & 4.3.2 Legal and other requirements & \\
\hline 4.3.3 Targets & 4.3.3 Long-term and short- term targets & 5.4.1 Quality targets \\
\hline 4.3.4 OHSAS management program & 4.3.4 Environmental management program & 5.4.2 Planning of QMS \\
\hline 4.4 Implementation and operation & 4.4 Implementation and operation & 7. Realization of product \\
\hline 4.4.1 Structure and responsibility & 4.4.1 Structure and responsibility & $\begin{array}{l}\text { Responsibility of management } \\
\text { Resource management }\end{array}$ \\
\hline 4.4.2 Training, awareness and competence & 4.4.2 Training, awareness and competence & $\begin{array}{l}\text { 6.2.2 Competence, awareness and training } \\
\text { of personnel }\end{array}$ \\
\hline 4.4.3 Consulting and communication & 4.4.3 Communication & 5.5.3 Internal communication \\
\hline 4.4.4 Documentation & 4.4.4 Documentation of EMS & 4.2 Documentation requirements \\
\hline 4.4.5 Documentation and data management & 4.4.5 Documentation management & 4.2.3 Control of documents \\
\hline 4.4.6 Operational management & 4.4.6 Operational management & $\begin{array}{l}7.1 \text { Planning of product realization } \\
\text { Processes related to customer }\end{array}$ \\
\hline 4.4.7 Emergency preparedness and response & 4.4.7 Emergency preparedness and response & $\begin{array}{l}\text { 7.1 Planning of product realization (partly) } \\
\text { 8.3 Control of nonconforming product }\end{array}$ \\
\hline
\end{tabular}

- Implementation and operation,

- Performance assessment,

- Improvement,

- Management review. [6], [9].

Comparison or determination of the common elements on the level of only two standards at the time

\section{QUALITY $\cap$ ENVIRONMENT}

Ecological friendliness of products and their production are increasingly assigned to one criteria of quality, which has to be considered by the organization, because of growing environmental awareness of customers. Therefore organizations today must take into account the society as a whole, not only their direct customers.

\section{QUALITY $\cap$ SAFETY}

An open relationship relies on the fact that the creation of the working environment as the role of health protection and safety at work has a direct impact on the quality of work and thus the quality of product, e.g. lighting conditions in the workplace etc.

\section{ENVIRONMENT $\cap$ SAFETY}

This intersection is particularly highlighted when the damage or potential hazards doesn't influence only employees in their workplace, but also to the surrounding environment, e.g. noise emissions, or hazardous substances in the air.
Comparison on the level of incompatibilities or specific elements of all standards

These elements may include the objectives of individual management systems, the complexity of their content, interest groups and the possible negative effects in the case of non regulation of these aspects.

\section{Benefits of Management Systems Integration and Obstacles of Integration}

Management system implemented according to ISO 9001, ISO 14001 and OHSAS 18001 is advantageous to implement and integrate into a single functioning management system, which will become a functional tool for managing and ensures the prevention of all the risks in the activities of the organization. This brings many advantages but also many barriers. Among the benefits of integration can be included:

- Avoidance of duplication and conflicts: The requirements of the various systems shall be arranged in particular activities of the organization and then common solutions are adopted.

- The benefits of synergies: Solutions that have already been proposed, may also be used for other systems.

- A comprehensive overview of the organization: the activities are analyzed and improved in the integration. If contradictory requirements are revealed, they are clarified and acceptable solutions are designed for all interested parties. 
- Optimizing cost management systems: necessary structures are commonly used, for example common documentation in one manual for the integrated management system.

The main barriers to the integration of management systems can be divided as follows:

- External reasons:

- Lack of standards for integrated management systems,

- Different understanding of existing standards,

- Lack of tools (or their nonuse) in auditing/management systems evaluation.

- Internal reasons:

- A formal approach to implementing systems,

- Promote the interests of different groups (e. g. quality at the expense of environment or safety)

- Effort to satisfy certification/consulting companies (also leads to a formal approach to the implementation of IMS).

\section{Integrated Management System Assessment}

IMS assessment is not only a problem for companies establishing and using integrated management systems, but also for the certification companies. These problems arise from the absence of standards for integrated system, the requirements for qualification of auditors of particular systems, but also from approaches to auditing or evaluation.
Assessment of an integrated management system in terms of its functionality and completeness should be conducted so that the compliance with requirements of the particular management systems forming IMS should be assured. In this case it means to assess the compliance with quality standards according to ISO 9001:2000, environmental standards according to ISO 14001:2004 and safety standards OHSAS 18001. IMS assessment should be done by a project team through internal audit and its results should be provided to top management of organizations. In case of discrepancies, it is necessary to take corrective measures, implement them and re-assess the system. For the assessment of IMS, it is appropriate to plan and conduct assessment systematically. Helpful tool in planning and carrying out audits is standard ISO 19011, which establishes certain principles and assists in planning and conducting the internal audit [6].

When assessing, it is essential that the project team asks the competent questions to which there may be a direct answer either yes or no, and that are aimed precisely at individual elements of standards of the basic module of IMS. The project team should create a catalog of questions or check list with questions related to particular standards. Table 2 shows the passage of control list for the assessment of an integrated system of quality, environmental and safety management.

Another approach to the evaluation of IMS is the use of risk management, as a common denominator of all management systems.

\begin{tabular}{|c|c|c|c|}
\hline & Yes & No & Note \\
\hline 5.3 Policy (quality + environment + safety) & & & Notes / Remarks: \\
\hline \multicolumn{4}{|l|}{ Does top management ensure that policy of quality: } \\
\hline 5.3-01 is compatible to purpose of the organization? & & & Unconformities: \\
\hline \multicolumn{4}{|l|}{$\begin{array}{l}5.3-02 \text { includes a commitment to meeting the requirements and to the constant improvement of the } \\
\text { effectiveness of quality, environment and safety management system? }\end{array}$} \\
\hline 5.3-03 provides a framework for setting goals and evaluating the quality, environmental and safety? & & & $\begin{array}{l}\text { Recommendations / } \\
\text { warnings: }\end{array}$ \\
\hline
\end{tabular}

5.3-04 was presented and understood within the organization?

5.3-04 was evaluated in terms of sustainability?

HSE 4.2-01 top management of organization established and documented environmental policy and policy of health and safety?

HSE 4.2-02 is policy appropriate in relation to the type, scope, environmental impacts and safety risks of operations, products and services of the organization?

HSE 4.2-03 includes a commitment to continuous improvement safety and health of employees and pollution prevention of the environment?

HSE 4.2-04 includes a commitment to complying with relevant environmental and safety laws and regulations and other requirements?

HSE 4.2-05 forms a framework for identifying and evaluating environmental and safety goals as well es partial goals?

HSE 4.2-06 is documented, implemented and maintained and is familiar to the staff?

HSE 4.2-07 is accessible to public? 
If the processes and their risks (e.g. risk to product quality, environmental risks and safety risks) are defined, each process can be monitored, measured and improved as a separate component measured by several performance indicators.

It is important to set parameters that are really important for management and for the operation.

An example of this approach is the Risk Based Assessment (RBA). This is a customer-oriented approach, where survey areas are determined on the basis of analysis of company management focused to the objectives, barriers to their achievement and their relation to the management areas (that covers all areas of management, including its relation to quality, environment, health and safety). This approach requires the involvement of management to the analysis and also to the results of an overall assessment.

RBA process consists of 5 steps:

- Identification and establishment of priorities of business objectives and barriers that may prevent their achievement.

- Definition of the importance of various areas of an ideal management system with respect to managing the obstacles defined in the first step.

- Evaluation of success of implementation in particular areas of the organization.
- Evaluation is scheduled in close cooperation with the senior leadership.

- Conduct the process of evaluation focused on several important areas under the resulting matrix of risks and report on any findings and areas for improvement.

\section{Conclusion}

Integrated management systems are now becoming an essential part of organizations that wish to manage their aspects effectively and efficiently and thereby increase their value on the market. Building an integrated management system, however, is left to the organizations themselves, which often lack the necessary information and support in the form of methodologies, guidelines and a variety of tools, which discourage many small and medium-sized organizations in the decision to implement IMS.

The IMS implementation in spite of many technical, economic and personnel problems, however, continues and is an important step on the way not only to the integration of enterprises in European and world trade area, but to the prosperity of business through more efficient management of risks associated with the quality of processes, environmental and safety risks.

\section{References}

[1] BERANEK, Z.: Experiences with Integrated Systems, Planeta, 2/2007, Czech ministry of environment, Praha. ISSN 1801-6898

[2] DUFINEC, I.: Virtual Process of Quality Management of Production in Integrated Management System of Company, Intern. conference proc. QUALITY 2002, DT Ostrava, VSB-TU Ostrava, 2002, ISBN 80-02-01494

[3] MAJERNIK, M. et al.: Conformity Assessment of Accreditation in the Field of Environmental, Safety and Quality Management, Environmental management for education and edification, Vol. 2, 2/2005, p. 34-39, ISSN 1336-5762

[4] MAJERNIK, M., CHOVANCOVA, J.: Environmental Management - Development and Trends, Environmental engineering and management, Conference proc. of 4th international conference EIaM 2007, Herlany, Kosice, SjF TU, 2007, p. 22-29, ISBN 978-808073-894-5.

[5] MANKO, M., LIBERKOVA, L., HRICOVA, B.: The Basic Access into the Integration Management Systems, Engineering sciences 1. oral presentation: 5th Intern. conference of PhD students, University of Miskolc, Hungary, 2005, Miskolc University, 2005, p. 129-132, ISBN 963-661-673-6

[6] MATIAS, J. C. O., COELHO, D. A.: The Integration of the Standards Systems of Quality Management, Environmental Management and Occupational Health and Safety Management, Int. Journal of Production Research, Vol. 40, No.15, Taylor \& Francis, 2004

[7] MORRIS, Alan S.: ISO 14000 Environmental Management Standards: Engineering and Financial Aspects, John Wiley \& Sons Ltd., 2004, ISBN 0-470-85128-7.

[8] RUSKO, M., BALOG, K., TUREKOVA, I.: Selected Chapters of Environmental and Safety Management, Bratislava, VeV et Strix, Edicia EV-4, First Slovak edition, 2006, ISBN 80-969257-5-X,

[9] SCHWENDT, S., FUNCK, D.: Integrierte Managementsysteme Konzepte, Werkzeuge, Erfahrungen, Physica, Heidlberg 2002, ISBN 3-7908-1442-3

[10] SMITH, D.: IMS. Implementing and Operating, British Standard Institution, London 2002, ISBN 058033328

[11] SMITH, D.: IMS. The Framework, British Standard Institution, London 2001, ISBN 0580332985. 